\title{
CRITIQUE OF THE CRIMINALISATION OF SEXUAL HIV TRANSMISSION
}

\author{
Amelia Evans*
}

This paper considers the extent to which people living with HIV or AIDS are liable for sexual conduct under New Zealand criminal law. After examining the ways in which the Crimes Act 1961 could be seen to criminalise sexual HIV transmission and exposure, this paper identifies two areas in which the existing law could be clarified and improved. First, by requiring a threshold "material level of risk" to be met before criminal liability is triggered and secondly by providing for disclosure as a defence where the threshold level of risk has been crossed. Clarification will ensure those people living with HIV and AIDS can knowingly act within the law. Once certainty of the law has been established, only then will social critique be viable.

\section{INTRODUCTION}

The implication from the Wellington District Court decision of Police $v$ Dalley, ${ }^{1}$ that a person is not legally obliged to disclose to a sexual partner if they suffer from the human immunodeficiency virus (HIV), shocked the public and led to widespread debate in late $2005 .^{2}$ However, despite the publicity given to the decision, there is still considerable uncertainty in the public domain about the extent of criminal liability for people living with HIV or AIDS $\left(\mathrm{PHAs}^{3}\right)$ and sexual conduct. ${ }^{4}$ The existence of widespread misinformation is hardly surprising, as the courts have failed to comprehensively articulate the position of law regarding several salient areas of HIV criminalisation. Given that over 1600 people in New Zealand have been diagnosed as HIV positive, and the number of diagnoses is increasing each year, ${ }^{5}$ it is imperative that the criminal law is sufficiently certain in order for PHAs to regulate their behaviour accordingly.

\footnotetext{
* Submitted as part of the LLB(Hons) programme at Victoria University of Wellington.

$1 \quad$ Police v Dalley [2005] NZAR 682 (DC).

2 Helen Tunnah "HIV case sparks moral debate" (7 October 2005) New Zealand Herald Auckland.

3 PHA is a internationally adopted inclusive term for people infected and living with HIV or AIDS.

4 See for example Frogblog http://blog.greens.org.nz (accessed 2 June 2006).

5 New Zealand AIDS Foundation http://www.nzaf.org.nz (accessed 11 July 2006).
} 
In light of this need, this paper endeavours to clarify the extent to which the law currently criminalises the sexual conduct of PHAs, highlight the areas of uncertainty that remain and provide guidance for how these uncertainties should be addressed. Part II of the paper begins by examining sections of the Crimes Act 1961 (the Act) applicable to sexual HIV transmission and exposure, ${ }^{6}$ in order to broadly define the limits of criminalisation. After establishing the bounds of the law under the Act, the deficiencies of the courts in applying this law are confronted. First, at Part III, an analysis of Dalley illustrates that the law inadequately addresses the relevance of the differing risks of transmission of HIV, if at all, to the culpability of PHAs. The likelihood of transmitting HIV is dramatically affected by a number of factors. This paper argues that the courts need to expressly identify a material level of risk in sexual interactions that will trigger criminal liability. The result will be that PHAs will be aware of the sexual acts permitted by law, as well as ensuring that differing charges result in consistent outcomes.

The second area where the courts have failed to be sufficiently clear is the effect disclosing one's HIV positive status to a sexual partner will have on criminal liability, as assessed in Part IV. After analysing three New Zealand cases that address disclosure and sexual HIV transmission, the paper proposes that the view the courts are likely to adopt in the future will be that whilst persons who know they are HIV positive are under a duty to use a condom, disclosure of their HIV status, coupled with consent to the sexual intercourse by their sexual partner, will operate as a defence where a condom is not used.

Any criminalisation of sexual HIV transmission will be controversial. The law is involving itself with policy considerations that range from sexual autonomy and privacy to health and discrimination. There can be no doubt that these policy considerations require careful assessment. However, the focus of this paper is on the equally troubling legal issues associated with criminalisation of HIV transmission, and seeking clarification of the expectations of the law with regard to PHAs. It is only once the criminal law is defined that it can be socially critiqued. Accordingly, an evaluative social and policy assessment of the law and its consequences remains outside the scope of this paper.

\section{CRIMINALISATION OF HIV IN NEW ZEALAND}

There are no statutory provisions specifically criminalising the sexual transmission of HIV in New Zealand. However the wide language of the Act captures three tiers of harmful behaviours by PHAs, reflecting differing levels of mens rea and whether the actus reus of actual HIV infection occurred.

6 Please note that this paper is limited to the criminalisation of HIV exposure through sexual transmission. Other modes of transmission, such as through blood transfusions and hypodermic needles, are not considered. 


\section{A Intentional Transmission}

The most serious criminal sanction for HIV exposure occurs when HIV is intentionally transmitted to another. Intentional HIV transmission is most likely to lead to a charge of "infecting with disease". ${ }^{7}$ The Court of Appeal has expressly acknowledged the appropriateness of this charge to the transmission of HIV, interpreting the section as simply to "have intended to cause or produce [HIV]" in another person. ${ }^{8}$ At the time of writing there had not yet been any charges laid under section 201, or any other section, regarding the intentional transmission of HIV. Indeed, proving intent to infect is likely to be difficult; in practice it would probably have to be inferred. ${ }^{9}$

\section{B Reckless Transmission}

However, the mens rea of intention to infect is not always required, and the courts have shown a willingness to use the more general sections of the Act to encompass HIV crimes with a lesser mens rea threshold. ${ }^{10}$ Where a defendant knows of his or her HIV positive status and is reckless as to its transmission, causing infection to occur, a charge of "wounding with intent" has been regarded as "pre-eminently appropriate". ${ }^{11}$ "Wounding with intent" is covered by section 188(2) of the Act, which requires "reckless disregard for the safety of others... [causing] grievous bodily harm to any person." 12 The Court of Appeal confirmed that having unprotected vaginal intercourse by not using a condom, without disclosing one's HIV positive status, causing HIV to be transmitted, is sufficient to meet the grounds of recklessness and accordingly charges under section 188(2) have been upheld. ${ }^{13}$ Conversely, obiter statements suggest that where a condom was used and HIV transmission nonetheless occurred, a charge of recklessness would fail, as discussed further in Part III.

\section{Exposure Without Transmission: Criminal Nuisance}

The third tier of criminalisation differs from the preceding two charges, as it does not require HIV to actually have been transmitted. Instead, the lesser charge of criminal nuisance has been held to apply where a defendant knows of his or her HIV positive status and acts in a way that endangers

7 Crimes Act 1961, s 201. However, other charges may be possible for example section 188(1) wounding with intent; more doubtfully a charge of culpable homicide may be applicable, see generally sections 15881, however note the section 162 limitation of the death occurring within a year and a day after the cause of death may be difficult to overcome given the nature of the HIV virus.

$8 \quad R v$ Mwai [1995] 3 NZLR 149, 152 (CA) Hardie Boys J for the Court.

$9 \quad$ Fran Wright "Criminal Nuisance: Getting Back to Basics" (2005) 21 NZULR 665, 669.

$10 \quad R v$ Mwai, above n 8; Police v Dalley, above n 1.

$11 R v$ Mwai, ibid, 153 Hardie Boys J for the Court.

12 Crimes Act 1961, s 188(2).

$13 \quad R v$ Mwai, above n 8. 
the health of another by risking infection, without that risk translating into actual infection. ${ }^{14}$ Assuming one does not first disclose his or her HIV positive status to a sexual partner, a charge of criminal nuisance is applicable to those who engage in unprotected vaginal intercourse, even if HIV is not actually transmitted. ${ }^{15}$ This is possible due to the wide language of section 145 , which states that a person is liable for criminal nuisance who: ${ }^{16}$

...does any unlawful act or omits to discharge any legal duty, such act or omission being one which he knew would endanger the lives, safety, or health of the public, or the life, safety, or health of any individual.

Consensual sexual interaction is not in itself an "unlawful act", even though such interaction may endanger a person's health where it involves contact with HIV positive bodily fluids. Therefore, in order for section 145 to apply to sexual HIV exposure it must be shown that PHAs are under a "legal duty" which they have omitted to discharge. There are two possible relevant legal duties that a PHA may be under: the first is a common law duty not to endanger others; the second is a statutory duty applicable to "persons in charge of dangerous things". ${ }^{17}$

1 The common law duty

The Court of Appeal in $R v M w a i^{18}$ held that PHAs "plainly" fall under the general common law duty "not to engage in conduct which one can foresee may expose others to harm". ${ }^{19}$ The Court also referred to a controversial Canadian case to support its reliance on the common law duty. There the Ontario Court of Appeal, in a decision upheld by the Supreme Court of Canada, held that the common law recognises: ${ }^{20}$

a broad fundamental duty to refrain from conduct which could cause injury to another person... At the very least, it requires everyone to refrain from conduct which it is reasonably foreseeable could cause serious harm to other persons.

In this context, a person knowing the ramifications of being HIV positive and who engages in sexual acts where bodily fluids containing HIV, exposes the other person to harm through the risk of

14 Ibid, Police v Dalley, above $\mathrm{n} 1$.

$15 R v$ Mwai, ibid.

16 Crimes Act 1961, s 145.

17 Crimes Act 1961, s 156.

$18 \quad R v$ Mwai, above $\mathrm{n} 8$.

19 Ibid, 156 Hardie Boys J for the Court.

$20 R v$ Thornton (1991) 1 OR (3d) 480, 485-486 (Ont CA) Galligan JA for the Court. Thornton donated HIV positive blood to the Red Cross, therefore exposing the public to the harm of HIV. Charges of criminal nuisance were upheld. 
transmitting HIV, a retrovirus which may destroy the immune system and lead to acquired immunodeficiency syndrome. ${ }^{21}$ As a result, a PHA is under a duty not to engage in such conduct.

There was some academic debate as to whether the Court was correct in extending the interpretation of "any legal duty"22 to include common law duties, on the basis that the Act is generally viewed as determinative of the content of criminal offences. ${ }^{23}$ However, subsequent confirmation from a later Court of Appeal decision that the words "any legal duty", 24 "...can include a legal duty arising at common law", ${ }^{25}$ shows that the courts are adopting a consistent belief that common law duties are incorporated into the Act, on the basis they are elements of an offence, rather than an offence themselves. ${ }^{26}$

Even so, the applicability of this common law duty seems doubtful. The cases cited in support of the general duty by the Court are all characterised by a particular person exposing multiple persons to harm through one act. ${ }^{27}$ However, a PHA engaging in sexual acts does not expose a community or multiple persons to harm, but another individual. This duty would correlate with the offence of nuisance prior to the re-drafting of the Act, which required endangering "the public", ${ }^{28}$ rather than only one individual.

\section{The statutory duty}

The courts in New Zealand have also referred to the statutory duty under section 156 when examining criminal nuisance and sexual HIV exposure. Section 156 provides a legal duty for persons in charge of dangerous things, and reads: ${ }^{29}$

21 D Morgan, C Mahe, B Mayanja, J M Okongo, R Lubega and J A Whitworth "HIV-1 Infection in Rural Africa: Is There a Difference in Median Time to AIDS and Survival Compared with that in Industrialized Countries?" (2002) 16 AIDS 597.

22 Crimes Act 1961, s 145.

23 See Wright, above n 9, 678-680.

24 Crimes Act 1961, s 160(2)(b): "Homicide is culpable when it consists in the killing of any person by an omission without lawful excuse to perform or observe any legal duty" (emphasis added).

$25 R v$ Lunt [2004] 1 NZLR 498, para 26 (CA) Blanchard J for the Court.

26 Ibid, paras 26-27 Blanchard J for the Court.

27 For example, taking a child infected with smallpox into a public place: $R v$ Burnett (1815) 4 M \& S 271; selling diseased meat: $R v$ Stevenson (1862) 176 ER 48; selling putrid cheese: Shillito $v$ Thompson (1875) 1 QBD 12 and donating blood known to be contaminated with HIV: $R v$ Thornton, above $\mathrm{n} 20$.

28 Criminal Code Act 1893, s 144.

29 Crimes Act 1961, s 156. 
Every one who has in his charge or under his control anything whatever... which, in the absence of precaution or care, may endanger human life is under a legal duty to take reasonable precautions against and to use reasonable care to avoid such danger....

The Court of Appeal in Mwai held that the bodily fluid of a PHA is "anything whatever" for the purposes of section 156, ${ }^{30}$ which through its ability to spread HIV, is capable of endangering human life. A person exercises control over his or her bodily fluids so, prima facie, it appears that the duty from section 156 to take reasonable precaution and care to avoid the danger of transmitting HIV applies to PHAs. While the Court accepted that there was a "strong argument that the statutory duty was established", it never decisively ruled whether the statutory duty applied, given that the wider common law duty plainly did. ${ }^{31}$

Earlier, when examining the two duties, the Court concluded that section 156 is merely a "particular aspect" of the wider common law duty. ${ }^{32}$ It seems preferable that, as there is some concern as to the suitability of the general common law duty, this specific statutory duty should be preferred. This is merely an extension of the general rule in law that the specific statutory provision is always applied in preference to the general. ${ }^{33}$ Indeed, when analysing the extent of the duty in both Mwai and Dalley, the analysis proceeded on the wording found in section 156, rather than the common law phrasing. ${ }^{34}$

Regardless of the duty employed, it is evident that a failure to discharge that duty through reasonable care will lead to a charge of criminal nuisance. The courts have recognised that using a condom during sexual intercourse will be regarded as reasonable care sufficient to discharge the duty and therefore render the defendant not guilty of the charge of criminal nuisance. ${ }^{35}$

\section{The Ambit of Criminalisation}

These three charges reflect the current criminal sanctions applicable to PHAs. While transmission of HIV is not requisite before one can be criminally liable, due to the operation of

$30 R v$ Mwai, above n 8, 156 Hardie Boys $\mathrm{J}$ for the Court.

31 Ibid, 157 Hardie Boys J for the Court

32 Ibid, 156 Hardie Boys J for the Court

33 This is sometimes referred to by the maxim generalia specialibus non derogant; see Seward v The Owners of The "Vera Cruz" (1884) 10 AC 59 (HL).

$34 \quad R v$ Mwai, above n 8, 156-157 Hardie Boys $\mathrm{J}$ for the Court and Police v Dalley, above n 1, paras 34-35 Judge Thomas.

35 Police v Dalley, above n 1, para 47 Judge Thomas. However, at Part III C it is argued that reasonable precautions are only required if a material risk of harm is exposed. 
criminal nuisance, it is apparent from the subjective nature of recklessness ${ }^{36}$ that knowledge of one's HIV positive status and the risks the disease presents to the health of others is a requirement.

However, the general nature of the charges in the Act means that the specific elements required before these charges can be successful have been left to the jurisdiction of the courts. Although a clearer position is now emerging concerning when the conduct of a PHA will be held to be criminal, the case law is far from cohesive. Significantly, the correlation between the risk of transmitting HIV - which varies greatly depending on the nature of the sexual act, protection used and individual concerned - and its effect on criminal liability is unclear. Further, the role that disclosure has on the criminal culpability of a PHA is yet to be decisively pronounced. The remainder of this paper addresses these two major legal ambiguities in an attempt to cohesively illustrate the application of the criminal law to sexual HIV transmission. The issues raised are pertinent to the lesser charges of intent to wound and criminal nuisance, whereas infecting with disease is an intentional crime which, as explained later, implies that disclosure and risk are of less relevance. Accordingly, intentional offences are not the focus of this paper.

\section{THE RELATIONSHIP BETWEEN THE RISK OF TRANSMISSION AND CRIMINAL LIABILITY}

Possibly due to a lack of litigation, the courts in New Zealand have not yet clearly articulated the effect the risk of HIV transmission has on criminal liability. ${ }^{37}$ Although in Dalley the Court acknowledged that, in the context of vaginal intercourse, taking the reasonable precaution of using a condom to lower the risk of transmitting HIV would absolve a defendant of a charge of criminal nuisance, ${ }^{38}$ the law remains in a confusing and unclear position. ${ }^{39}$ For example, will using a condom also be sufficient to dispel criminal charges if the sexual activity is anal intercourse, where the risk of HIV transmission is significantly higher than vaginal intercourse? ${ }^{40}$ Alternatively, do any reasonable precautions need to be taken in forms of sexual conduct, such as mutual masturbation, where the risk of transmission is virtually non-existent? ${ }^{41}$

$36 \quad R v$ Harney [1987] 2 NZLR 576 (CA). For further discussion see Part II D 2.

37 Although in $R v$ Brown [1994] 1 AC 212 (HL) the majority regarded any potential risk of serious bodily harm as sufficient to justify criminalisation, that position is unlikely to be adopted to in New Zealand given the significance attributed to risk in Police $v$ Dalley, above $\mathrm{n}$ 1, as explained in Part III B, and the dissatisfaction with $R v$ Brown in $R v$ Yong Bum Lee (7 April 2006) CA437/04 as explained further in Part IV B.

38 Police v Dalley, above n 1, para 49 Judge Thomas.

39 See Part III B.

40 Carol L Galletly and Steven D Pinkerton "Toward Rational Criminal HIV Exposure Laws" (2004) 32 JLME 327, 328.

41 R A Royce, A Seña, W Cates JR and MS Cohen "Sexual Transmission of HIV" (1997) 336 N Engl J Med 1072, 1073. 
Ignoring these questions leaves open a void of uncertainty regarding which sexual acts a PHA is permitted to do, and which are forbidden by law. Ensuring that the criminal law is sufficiently certain and that citizens can ascertain how the law requires them to regulate their conduct is one of the underlying principles of criminal law ${ }^{42}$ so that "a citizen, before committing himself to any course of action, should be able to know in advance ... [the] legal consequences that will flow from it". ${ }^{43}$ To provide this certainty, and ensure a rational relationship between harm and criminalisation, this paper advocates that an identifiable level of risk of harm be established. Where a PHA partakes in behaviour that is more risky than this material threshold of risk of harm would allow, that behaviour should be criminalised. Conversely, where a PHA partakes in behaviour that has a risk of transmitting HIV below this designated material level, that behaviour is lawful. Establishing such a material level of risk of harm can be achieved by interpreting the word "endanger" in section 145 as implicitly requiring a material level of endangerment.

\section{A Risk is Relevant to Offences of Recklessness}

It is well established by case law that the risk of harm is an integral inquiry into offences of recklessness. ${ }^{44}$ Indeed, recklessness is defined as the conscious taking of an unjustifiable risk. ${ }^{45}$ Accordingly, the risk of harm - that is the risk of transmitting HIV - must be assessed where charges of intent to wound or criminal nuisance are applied, as both are offences of recklessness. Intent to wound, a charge imposed where HIV is transmitted, statutorily proscribes a mens rea level of recklessness. ${ }^{46}$ Where HIV is not transmitted, criminal nuisance applies, and although recklessness is not specifically prescribed in the statute, ${ }^{47}$ the Court of Appeal has nonetheless held criminal nuisance to be "an offence of recklessness". ${ }^{48}$ By implication, risk is clearly relevant to the sexual transmission of HIV, regardless of whether HIV was in fact transmitted.

\section{Differing risks of transmission}

The requirement to evaluate risk presents the courts with a challenge, as not all sexual activities have the same risk of transmission. The reality is that different activities entail significantly different risks. For example, in male-to-male sexual conduct, the risk that unprotected anal intercourse will lead to infection is approximately 1 in 50 where the infected male is the insertive partner; ${ }^{49}$ whereas

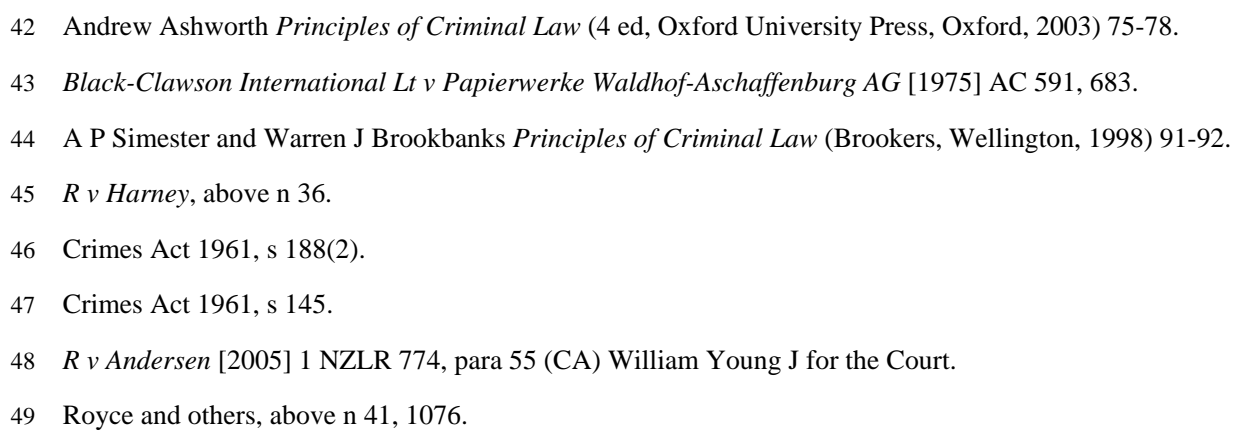


the risk that unprotected oral intercourse will lead to infection is approximately 1 in 2500 where the infected male is the insertive partner. ${ }^{50}$ Thus the risk of one form of sexual conduct causing harm is 50 times greater than the other. As blood, semen, saliva, urine and faeces are all potentially infectious bodily fluids, ${ }^{51}$ the range of sexual activities that risk transmitting HIV is extensive, and as each act generates its own unique level of risk, the correlated risk of harm is equally wideranging.

\section{B Dalley: The Current Approach to Risk Under the Law}

Only one New Zealand case, Dalley, has directly considered how the risk of transmitting HIV affects criminal liability, and this discussion was limited to the charge of criminal nuisance, without reference to the relevance of risk under a charge of intent to wound. ${ }^{52} \mathrm{Mr}$ Dalley knew of his HIV positive status, however he did not inform the complainant of his condition before having unprotected oral and protected vaginal intercourse, leading to two charges of criminal nuisance.

Judge Thomas rejected the proposition that Dalley was under a positive duty to disclose his condition. 53 Instead, her judgment focussed on how Dalley effectively practiced "safer-sex" methods such that the requirement under the statutory duty to take reasonable precautions was met. Hence both criminal nuisance charges were dismissed. ${ }^{54}$ However, as discussed further below, close analysis of the reasoning in Dalley shows that the decisive factor in Judge Thomas' decision was not so much whether Dalley took reasonable precautions to avoid danger, as required by the plain words of the statutory duty, ${ }^{55}$ but whether the level of risk of transmitting HIV that Dalley exposed the complainant to in fact exceeded a material level of risk of harm.

\section{Risk and reasonable precautions}

Judge Thomas' decision that protected vaginal intercourse, through condom use, did not breach section 156, was based on comparative rates of HIV transmission. It was accepted that unprotected vaginal sex, where the male is HIV positive, has a likelihood of transmitting HIV to a female of between 0.1 to 5.75 per cent. However, the risk of transmitting HIV through vaginal intercourse

50 E Vittinghoff, J Douglas, F Judson, D McKirnan, K MacQueen and SP Buchbinder "Per-contact Risk of Human Immunodeficiency Virus Transmission between Male Sexual Partner" (1999) 150 American Journal of Epidemiology 306, 309.

51 Randall A Coates and Martin T Schechter "Sexual Modes of Transmission of the Human Immunodeficiency Virus (HIV)" (1988) Annals of Sex Research 115, 121.

52 Police v Dalley, above n 1.

53 For a full discussion of the disclosure aspect of the decision see Part IV A.

54 Police $v$ Dalley, above $\mathrm{n} 1$.

55 Crimes Act 1961, s 156. 
when a condom is used drops to approximately 0.00005 per cent. ${ }^{56}$ Consequently, Dalley satisfied the duty to take reasonable care to avoid transmitting HIV, as his condom use significantly reduced the risk of transmission. In essence, Judge Thomas seems to be accepting that if a defendant reduces the risk of harm to a minimal level, the requirements of the legal duty to take reasonable precautions to avoid danger ${ }^{57}$ are sufficiently met.

However, the purported reliance in her reasoning that Dalley took "reasonable precautions" falters when she finds that there was no breach of the legal duty to avoid harm concerning unprotected oral intercourse. Judge Thomas considered two factors relevant: first, as Dalley withheld ejaculation during oral intercourse, there was only a small amount of pre-ejaculation fluid with which the complainant came in contact; secondly, it was accepted in evidence that the risk of transmission was very low for unprotected oral intercourse. ${ }^{58}$

No explanation was given as to why withholding ejaculation was relevant to determining if there was a breach of the statutory duty. However, it would be difficult to justify that withholding ejaculation amounts to taking reasonable care or precaution to avoid danger under section 156 . The Court of Appeal, albeit in the context of evidence, held there is no discernible difference between sexual encounters where ejaculation does and does not occur. ${ }^{59}$ Ejaculation is medically regarded as a reflex; control of the reflex is physical not mental, thus an intent to withhold or prevent ejaculation may not translate to a physical ability to withhold. ${ }^{60}$ Accordingly, it is doubtful that Judge Thomas intended to suggest the fact that Dalley failed to ejaculate equated to taking a reasonable precaution to discharge the section 156 duty. Such a suggestion would be contrary to health policy that strongly discourages unprotected intercourse and withdrawal as a form of sexual protection, ${ }^{61}$ as it would promulgate the discredited idea that withdrawal or not ejaculating equates to safe sexual health.

Therefore it must be deduced that Judge Thomas considered that withholding ejaculation was relevant not because it was a means of taking reasonable care, but because it lessened the amount of bodily fluid the complainant had contact with, therefore lowering the likelihood of transmitting HIV. ${ }^{62}$ That is, the risk of transmission was lowered. This analysis supports the other factor Judge

56 Police v Dalley, above n 1, para 21 Judge Thomas.

57 Crimes Act 1961, s 156.

Police v Dalley, above n 1, paras 37-39 Judge Thomas.

9 v Urwin (3 May 2004) CA 476/03, para 18 Baragwanath J for the Court.

60 H F Newman, H Reiss, J D Northup "Physical Basis of Emission, Ejaculation, and Orgasm in the Male" (1982) 19 Urology 341, 347.

61 See for example Family Planning Association New Zealand www.fpanz.org.nz (accessed 12 July 2006).

62 Michael Samuel and Alan R Lifson "What Does Risk Mean?" The Body: Complete HIV/AIDS Resource www.thebody.com (accessed 17 August 2006). 
Thomas held to be relevant: that although the possibility of HIV transmission through unprotected oral sex was biologically plausible, "it is so low it does not register as a risk."63 These factors both merely indicate that the level of risk associated to unprotected oral intercourse is minimal. Neither withholding ejaculation nor the extraordinarily low risk in unprotected oral intercourse can rationally be considered as "taking reasonable precaution against or reasonable care to avoid danger"; 64 they simply point to the risk of the danger being inherently low. Therefore it seems that the basis of Judge Thomas' decision is the level of risk of harm exposed to a complainant, rather than whether "reasonable care and precaution" was taken.

\section{C "Endanger" in Section 145 Implicitly Requires a Material Risk of Harm}

Accordingly, this author believes the result in Dalley can be satisfactorily reconciled by a tacit justification: a PHA will only be acting unlawfully if he or she exposes a person to a risk of harm above a "material level". In such an event, a PHA has a duty to take reasonable precautions to reduce the risk of harm to below this material threshold in order to absolve criminal liability.

Applying this rationale to Dalley, unprotected vaginal intercourse had an accepted risk of between $0.1-5.7$ per cent. Given that the resulting harm of HIV transmission is the potentially fatal AIDS, such a risk, although statistically low, was nonetheless considered to be over the "material" threshold by Judge Thomas. Thus Dalley was under a duty to take reasonable precautions to reduce the risk. This was achieved by using a condom, which lowered the risk of transmission to approximately 0.00005 per cent. Judge Thomas must have regarded such a risk as below the "material" threshold. Further, as unprotected oral intercourse inherently has a risk of transmission similar to protected vaginal intercourse, ${ }^{65}$ this too must have been below the "material" threshold. Therefore Dalley, by only partaking in acts below this threshold, was not criminally liable.

Expressed another way, to trigger the duty to reasonable care under section 156, there must first be a material risk of harm. That is, PHAs who fail to discharge their duty to take reasonable care and precaution would only face a charge of criminal nuisance if the failure would materially "endanger the... health of any individual" under section $145 .{ }^{66}$ This interpretation of "endanger" in section 145 is consistent with an earlier Court of Appeal decision. There the Court stated that: "[t]he conduct of the appellants 'would endanger' the lives, safety, or health of the public or any individual if it would materially add to the risk of the public or any individual being infected...". ${ }^{67}$ As a result a PHA is

63 Police v Dalley, above n 1, para 19 Judge Thomas.

64 Crimes Act 1961, s 156.

$650.00005-0.0001$ per cent was the level of risk of transmission in unprotected oral intercourse accepted in evidence Police $v$ Dalley, above n 1, para 19 Judge Thomas, which is the same as protected vaginal intercourse, at para 21.

66 Crimes Act 1961, s 145

$67 \quad R v$ Turner (1995) 13 CRNZ 142, 151 (CA) Tompkins J (emphasis added). 
under a duty to take reasonable precautions to ensure that the risk of harm exposed to others is below a material level. If the level of harm is below that material level, as in unprotected oral intercourse, then no precautions need to be taken.

Admittedly, the rationale implicit in requiring a material level of risk seems to have been conceptually disapproved of by Judge Thomas, who rejected an argument by defence counsel that the words "endanger human life" in section 156 required "a significant risk" of endangerment. ${ }^{68}$ The submission was rejected on the basis that a strict interpretation of "endanger" in section 156 did not require a significant risk; rather the plain words merely imply that human life be at any risk of harm, regardless of the likelihood of endangerment, before a duty to take reasonable care is imposed. ${ }^{69}$

It is possible to again reconcile this apparent internal inconsistency by recognising the difference between the meaning of "significant" versus "material", the plain language of former implying a greater likelihood of harm than the latter. Therefore rejecting a requirement of significant risk when interpreting "endanger" does not rule out permitting the requirement of a material risk. Further, the refusal to read-in a requirement of significant risk seems to be based on the fact that, as a district court judge, Judge Thomas is bound to follow the Court of Appeal's decision that a PHA is "plainly"70 under a legal duty. ${ }^{71}$ If she had accepted that a significant risk is required, she may have been in the conflicting position of finding Dalley did not present a significant risk of harm and therefore was not under a legal duty. Either way, Judge Thomas' objection to such a requirement is unnecessary as it seems irrefutable that a PHA may expose others to a significant risk of harm; ${ }^{72}$ it is merely that as different modes of exposure present differing risks, not all exposures will result in significant risk of harm.

\section{Consistency between harm and criminalisation}

If the statutory interpretation of "endanger" supposedly advocated by Judge Thomas were applied, which stringently requires reasonable precaution to be taken if there is any risk of harm, as opposed to a "material" risk of harm, the result would be anomalous. To illustrate this, take the example of a sexual act with a very low risk of harm, such as partner-masturbation. ${ }^{73}$ If an

68 Police v Dalley, above n 1, para 33 Judge Thomas.

69 Ibid, para 35 Judge Thomas.

$70 R v$ Mwai, above n 8, 156 Hardie Boys $\mathrm{J}$ for the Court.

71 Police v Dalley, above n 1, para 35 Judge Thomas.

72 See, for example, the risks of transmission for intravenous drug users and blood transfusions in Canadian AIDS Society "Disclosure of HIV Status After Cuerrier: Resources for Community Based AIDS Organizations" www.cnaids.ca (accessed 16 July 2006).

73 The risk of transmission is almost zero and is statistically insignificant. See Galletly and Pinkerton, above n 40, 329. 
interpretation of "endanger" did not require a material risk of harm but merely exposure to any risk of harm, a PHA would be under a duty to take reasonable care or precaution. However, in this example there are no positive acts that would amount to taking reasonable care or precaution, ${ }^{74}$ and so a charge of criminal nuisance would be upheld.

Yet the actual risk of transmission for partner-masturbation is substantially lower than other sexual acts where reasonable precaution has been taken. For example, protected vaginal intercourse has a higher risk of transmitting HIV than "unprotected" partner-masturbation; ${ }^{75}$ nevertheless it has been held that protected vaginal intercourse is not criminal nuisance, ${ }^{76}$ whereas under the "any risk" interpretation of endanger, partner-masturbation would be criminal nuisance. Such an outcome, that a sexual act which has a lower risk of harm irrespective of whether precaution is taken entails criminal liability, while a protected act with a greater risk does not, is both irrational and arbitrary. Further, such a result would conflict with the purpose of criminal nuisance, which is to prevent harm, ${ }^{77}$ as it potentially criminalises acts less likely to cause actual harm, while permitting acts with a greater likelihood of harm.

Alternatively, if exposing a complainant to a material risk of harm were a requisite condition of criminal nuisance, it can be assured that there will always be a rational connection between the risk of harm and criminalisation. Failure to have this connection has been severely criticised in overseas jurisdictions, ${ }^{78}$ a mistake the New Zealand courts can easily avoid by interpreting the word "endanger" in section 145 to imply a material risk of harm, rather than just "any" risk of harm.

\section{Consistency between criminal nuisance and intent to wound}

Further, a failure to incorporate a material risk of harm into criminal nuisance would overlook the fact that nuisance, like intent to wound, is an offence of recklessness. ${ }^{79}$ No case has yet discussed the implications and consequences criminal nuisance being an offence of recklessness, however as recklessness is the "conscious taking of an unjustifiable risk", ${ }^{80}$ it would seem risk must be regarded as a central part of to nuisance inquiry, just as it is with intent to wound.

74 The Online English Oxford Dictionary defines both "care" and "precaution" as "modes of action": The Oxford English Dictionary www.oed.com (accessed 28 July 2006).

75 Galletly and Pinkerton, above n 40, 336.

76 Police v Dalley, above n 1.

77 Wright, above n 9, 668.

78 Galletly and Pinkerton, above n 40, 329.

$79 R v$ Andersen, above $\mathrm{n} 48$, para 55 William Young $\mathrm{J}$ for the Court.

$80 \quad R v$ Harney, above n 36. 
The mens rea of recklessness necessitates balancing the likelihood, nature and gravity of the harm, against the value of the conduct. ${ }^{81}$ Applying this concept to sexual HIV transmission, the Court of Appeal in Mwai was prepared to accept that despite the gravity and nature of the harm ultimately being the transmission of a life-threatening virus, if a condom had been used for vaginal intercourse, the risk would have been sufficiently lowered so that charges of intent to wound would have failed. ${ }^{82}$ Expressed in terms of risk, the value of allowing consensual intercourse must outweigh the risk of suffering "one of the most unpleasant illnesses a person can suffer from", 83 providing the risk of harm is equal to, or below that, associated with protected vaginal intercourse, the level of risk impliedly permitted in Mwai. That is, the behaviour is permissible if it is below a material risk of harm.

If this material risk of harm was not required when interpreting "endanger" in criminal nuisance, but was regarding intent to wound, then not only would this run contrary to the Court of Appeal decision that criminal nuisance has the mens rea of recklessness; ${ }^{84}$ it would also mean that criminal liability would hinge on whether HIV was actually transmitted. Such a position is untenable: 85 where HIV was transmitted, the charge of intent to wound would apply, and thus the risk of harm would be a crucial inquiry; where HIV was not transmitted, the charge of criminal nuisance would apply and the risk of harm would not be central. As a result, a PHA, performing a sexual act, may be criminally liable if HIV is not transmitted, whereas if HIV is transmitted there may be no liability.

To best illustrate how such an abhorrent inconsistency is possible, the previous example of an inherently low-risk sexual activity, such as partner-masturbation, is useful. ${ }^{86}$ If a material risk of harm was not required, performing such a low-risk activity, which did not transmit HIV, would result in a conviction of criminal nuisance. ${ }^{87}$ However, if in fact HIV was transmitted, the charge would be intent to wound, which without doubt requires a risk analysis due to its express inclusion of recklessness. As the risk of harm for partner masturbation is below that of protected vaginal intercourse, a level risk implicitly permitted in Mwai, by implication a charge of intent to wound

81 Hilder v Police (1989) 4 CRNZ 232, 236-7 (HC) Wylie J.

$82 R v$ Mwai, above n 8, 152 Hardie Boys $\mathrm{J}$ for the Court.

83 Ibid, 153 Hardie Boys J for the Court.

$84 R v$ Andersen, above $\mathrm{n} 48$, para 55 William Young $\mathrm{J}$ for the Court.

85 Although it is not uncommon to have differing criminal standards applied depending on whether harm occurs, such instances are based on the rationale that where harm has eventuated a greater penalty is deserved than if risk of harm was merely present. Such a justification does not apply to the HIV transmission cases, as they would impose a greater penalty where harm did not occur.

86 See Part III C 1 for background.

87 This result is explained fully in Part III C 1. 
would fail. Such an outcome, where one performs the same act, and is liable if HIV is not transmitted yet exculpated if HIV is transmitted, is intolerable. As a result, construing "endanger" to require a material risk can be viewed as necessary for the offences of recklessness to operate cohesively together.

\section{Designating the Material Level of Harm}

Currently, following the implications in Dalley and Mwai, the courts seem to criminalise exposure to a risk of transmission at some level greater than protected vaginal intercourse, or 0.00005 per cent. ${ }^{88}$ This paper does not intend to confirm whether this is an optimal level of material harm, as the medical knowledge and social policy consequences involved are far too extensive. Indeed setting such a level would be a task for Parliament or health policy specialists to undertake. Nonetheless, some legal insights about adopting a pragmatic material level of risk of harm are provided.

\section{Problems of measurement}

First, the measurement of HIV transmission rates are only approximates, with some studies producing staggeringly different rates for the same method of transmission, making the level of risk difficult to ascertain. This is compounded by the range of factors affecting individual susceptibility to HIV, such as having lesions, disrupted tissue, or poor oral hygiene. The quantity of the virus in the bodily fluids, administration of antiretroviral drugs, and strength of a person's immune system can also greatly vary the risk of transmission between individuals. ${ }^{89}$ Potentially, this could cause difficulty in ascertaining a material level of risk of harm.

However, although ascertaining precise levels of risk may be difficult, it is generally accepted that it is possible to broadly rank or classify the level of risk associated with certain activities. In Canada, where a "significant risk of serious bodily harm" is required, ${ }^{90}$ the courts have accepted like New Zealand - that unprotected vaginal intercourse exposes a complainant to a significant risk of harm, ${ }^{91}$ but that unprotected oral intercourse does not. ${ }^{92}$ A specific level of the risk of harm has not been set by the courts or legislature in Canada, although in practice community based AIDS organisations are adopting the Canadian AIDS Society standards when advising PHAs of their legal obligations. These standards identify unprotected vaginal and anal intercourse, and "inserting a sex

\footnotetext{
88 Police v Dalley, above n 1, para 21 Judge Thomas.

89 Royce and others, above n 41, 1075.

$90 \quad R v$ Cuerrier [1998] 2 SCR 371, para 128 Cory J (Major, Bastarache and Binnie JJ concurring).

91 Ibid, para 128 Cory J (Major, Bastarache and Binnie JJ concurring).

$92 \quad R v$ Edwards (2001) 194 NSR (2d) 107.
} 
toy into the anus or vagina after a sexual partner has inserted it in her vagina or anus, or his anus" as significant risk activities. ${ }^{93}$

This classification approach disregards the individual variations discussed above by looking only to the risk of the activity itself. Moreover, it does not set a fixed quantifiable level of risk. Such an approach is not exact, however evidentially ascertaining the exact risk of HIV transmission would be impossible with hindsight given the changing variables anyway. Such an approach seems both desirable and achievable, providing clear guidelines of legally permissible sexual conduct to PHAs while retaining a rational connection between risk and criminalisation.

\section{Knowledge}

Finally, as recklessness is subjective, ${ }^{94}$ it is clearly necessary that PHAs, when diagnosed, are fully informed of the risks attached to differing activities, as well as the legal implications of each. Current practice seems already to be to advise PHAs about the risk associated with differing sexual acts, ${ }^{95}$ so this knowledge requirement may present few problems. Nonetheless, if guidelines about material risk are to be put forward, such as those available through the New Zealand AIDS Foundation, ${ }^{96}$ they must advocate a consensus position of risk in New Zealand as recognised by the courts, and be clearly explained to PHAs as well as being freely available to the public.

Requiring a publicly-known material level of the risk of harm for both criminal nuisance and intent to wound is necessary to achieve consistency between the two offences and achieve a rational connection between harm and punishment, as the purpose of criminal law commands. Not only is such a position rational, it is also desirable, as it will provide a practical transparency to the law, so that PHAs can conduct their affairs with the knowledge they are acting outside the bounds of criminality.

\section{THE RELEVANCE OF DISCLOSURE}

However, even if the law is clarified by requiring a material level of harm when assessing the risk of HIV transmission, a further ambiguity remains; concerning the relevance of disclosure. Although there have been recent cases before the courts concerning the impact of disclosure on criminal liability ${ }^{97}$ and consent, ${ }^{98}$ the courts have failed to definitively declare the effect and

93 "Disclosure of HIV Status After Cuerrier", above n 72. The guidelines also list sharing needles as a highrisk activity, however as it is a non-sexual activity it is outside the scope of this paper.

$R v$ Harney, above $n 36$.

95 Police v Dalley, above n 1, para 15 Judge Thomas and New Zealand AIDS Foundation www.nzaf.org.nz (accessed 11 July 2006).

96 New Zealand AIDS Foundation, ibid.

97 Police v Dalley, above $n 1$.

$98 \quad R v$ Yong Bum Lee, above n 37. 
relevance of disclosure to alleged criminal conduct by PHAs. Overseas jurisdictions have established varying positions on the relevancy of disclosure. In Canada, there is a positive requirement to disclose one's HIV positive status whenever there is "a significant risk of serious bodily harm". ${ }^{99}$ Failure to disclose in such circumstances may amount to a fraud that can vitiate consent to the intercourse, resulting in conviction of a sexual offence. ${ }^{100}$ Conversely, in the United Kingdom, disclosure of serostatus to a sexual partner provides a defence to grievous bodily harm, through informed consent, where HIV is transmitted through unprotected intercourse. ${ }^{101}$

It is clear therefore that disclosure is capable of having a substantial impact on the culpability of PHAs. It is imperative that the relevance of disclosure in the New Zealand judicial system be clearly espoused so that HIV persons can regulate their behaviour accordingly. ${ }^{102}$ Instead, the discussion of disclosure in the New Zealand judicial system has been at times confused and unclear. However, a close analysis of the case law seems to suggest that disclosure may operate as a defence to criminal charges applicable when a PHA exposes a sexual partner to a material risk of harm. ${ }^{103}$ This, it is argued, is both a desirable and practical position.

\section{A Refuting Disclosure as a Positive Duty in Dalley}

The most direct discussion concerning the role of disclosure emerged in Dalley. There the ruling that using a condom fulfils the requirement in section 156 to take reasonable care, even if one does not disclose his or her HIV positive status, implies that there is no positive, overriding duty to disclose. It was the refusal to rule that PHAs are legally obligated to disclose their serostatus prior to intercourse that made the decision publicly controversial; ${ }^{104}$ as Judge Thomas stated: ${ }^{105}$

It seems to me that most people would want to be told that a potential sexual partner was HIV positive.

There may well be a moral duty to disclose that information. There is however a difference between a moral duty and a legal duty, the legal duty in this case being to take reasonable precautions against and use reasonable care to avoid transmitting the HIV virus.

$99 R v$ Cuerrier, above n 90, para 128 Cory J (Major, Bastarache and Binnie JJ concurring).

100 Ibid, para 127 Cory J (Major, Bastarache and Binnie JJ concurring).

$101 R$ v Dica [2004] EWCA Crim 1103; $R$ v Konzani [2005] EWCA Crim 706.

102 Ashworth, above n 42, 75-78.

103 See Part III for a full discussion of why only exposing a sexual partner to a material risk of harm will result in criminal charges.

104 Danya Levy "HIV-positive man did not have to tell partner, court rules" (5 October 2005) New Zealand Herald Auckland.

105 Police v Dalley, above n 1, para 43 Judge Thomas. 
However, whether this comment in Dalley implies that disclosure, by itself, will never be capable of discharging the duty under section 156 is unclear. On one reading the above extract does seem to suggest that only using a condom will discharge section 156, as disclosure is simply a "moral duty", which does not exculpate one from criminal liability. Under such an interpretation a PHA who disclosed his or her status to a sexual partner and then did not take the reasonable precaution of using a condom would be criminally liable, even if the partner knowingly consented to, or desired, unprotected intercourse. Such an outcome would greatly undermine the sexual autonomy of individuals - although such paternalism is not uncommon throughout the criminal law. ${ }^{106}$

Although never expressly stated, it is not difficult to understand why Judge Thomas did not impose a positive duty to disclose once the words of section 156 are examined. The duty requires that "reasonable care to avoid such danger" 107 must be taken: disclosing whether one is HIV positive to someone alone does not avoid or prevent the transmission of that virus. Disclosure provides a potential sexual partner with greater information about the nature of the risk involved in a sexual interaction, but does not actually alter the risk of harm. Consequently, it might be somewhat contrived to argue that disclosure, without more, discharges the section 156 duty to avoid the harm of HIV.

\section{B Disclosure as a Defence}

While it does not appear that Dalley leaves open the possibility of disclosure discharging the legal duty under section 156, nonetheless it does not entirely prevent disclosure being used as a means of exculpation. This is because the possibility that disclosure may nevertheless operate through the defence of consent is not expressly denied in Dalley, as such a ruling was outside the ambit of the District Court inquiry. Consent as a defence to HIV transmission is, however, supported by obiter comments in two Court of Appeal decisions. Consent would not be automatically rejected as a defence, as the law concerning the defence of consent has recently undergone radical change. ${ }^{108}$ While previous case authority would have suggested that as HIV transmission is considered grievous bodily harm, ${ }^{109}$ unless it fell within a recognised exception, such as surgery or body piercing, the defence would not be open. ${ }^{110}$ Consent may now be

106 Simester and Brookbanks, above n 44, 10-11.

107 Crimes Act 1961, s 156.

108 See $R v$ Yong Bum Lee, above n 37, paras 289-310 Glazebrook J for the Court, where the previously adopted majority position in $R v$ Brown, above $\mathrm{n} 37$, was rejected in favour of the minority position expressed by Lord Mustill.

$109 R$ v Mwai, above n 8, 153 Hardie Boys J for the Court.

$110 R v$ Brown, above $\mathrm{n} 37$. However, even under the traditional position the risk of HIV transmission may have been considered such an exception, see $R v$ Wilson (Alan) [1996] 3 WLR 125 for an example. 
considered a defence where a defendant was reckless causing grievous bodily harm "... unless there are good public policy reasons to forbid it and those policy reasons outweigh the social utility of the activity and the value placed by our legal system on personal autonomy."111

Clearly there are significant personal autonomy interests ${ }^{112}$ and social utility benefits ${ }^{113}$ attributable to permitting PHAs and their sexual partners to continue their consensual sexual relations. Although a full analysis of policy considerations is outside the ambit of this paper, strong public policy justifications would be required to overcome the presumption of the defence being open. Therefore, it seems sensible to assume that consent would not be automatically withdrawn as a defence. This assumption is firmly supported and evidenced by the judicial comments and arguments outlined below.

\section{$1 \quad R v$ Mwai}

Mwai had unprotected sexual intercourse with several women without disclosing his known HIV positive status. He transmitted HIV to two women, and was charged and convicted under section 188(2) for reckless transmission of HIV. Charges of criminal nuisance were also successfully brought regarding other women to whom he exposed, but did not transmit, HIV. ${ }^{114}$ As Mwai neither used a condom nor disclosed his status, the role and relationship between disclosure and condom use was not directly at issue in Mwai. Nonetheless, the Court was open to viewing disclosure as a definite means of exculpating liability, as evidenced in its discussion of the section 156 duty: ${ }^{115}$

[Defence counsel conceded it would] ...be more appropriate to see Mwai's duty as one to disclose his condition so that his sexual partner understood the risk of engaging in unprotected intercourse with him. It is certainly arguable that there would be no duty [to use a condom] if the partner consented to run the risk. Seen in this way, the duty to use a condom would arise only if there were a failure to disclose.

Furthermore, the Court earlier stated that one of the issues in the case was "the contention that Mwai having failed to warn his sexual partners of his condition, was criminally responsible for not taking the precaution of using a condom". ${ }^{116}$ Both of these comments indicate that disclosure would

$111 R v$ Yong Bum, above n 37, para 316, Glazebrook J for the Court.

112 See part IV A and also Matthew Weait "Knowledge, Autonomy and Consent: $R v$ Konzani" [2005] Crim LR 763; Helen Law "Court of Appeal: Offences against the Person: Reckless Transmission of HIV" (2005) 69 JoCL 389.

113 For example, minimising discrimination against PHAs. See further $R v$ Dica, above $\mathrm{n} 101$, paras 47-56 Judge LJ for the Court.

$114 R v$ Mwai, above n 7, 151-2 Hardie Boys J for the Court.

115 Ibid, 156 Hardie Boys J for the Court (emphasis added).

116 Ibid, 152 Hardie Boys J for the Court (emphasis added). 
absolve criminal liability. However, precisely how disclosure would function as a means of exculpation, whether as a defence or as a duty, is not made clear. This paper argues that the Court, as is made clear in subsequent decisions, ${ }^{117}$ intended disclosure to operate as a defence, not a duty.

The Court of Appeal initially began its discussion of disclosure by using language that seemed to indicate it viewed the role of disclosure as being a duty capable of discharging section 156 . This is evident in the opening statements "... [the defence counsel conceded it would] be more appropriate to see Mwai's duty as one to disclose...". ${ }^{118}$ However, the author submits that this phrase is not to be interpreted as implying a positive duty under section 156, or even that it might be construed as an alternative duty capable of discharging section 156 in the same way Dalley held using a condom discharges the duty. ${ }^{119}$ While the latter interpretation of Mwai has been adopted by some academics, ${ }^{120}$ it is submitted that the Court of Appeal's comments on disclosure should be construed as proposing that if a defendant were to rely on the defence of consent where unprotected sexual conduct had occurred, such a defence would only succeed if his or her HIV positive status had been disclosed prior to the sexual interaction. Expressed in another way, a breach of section 156 would still occur where there is unprotected sexual contact and therefore the actus reus of criminal nuisance would be fulfilled; however the defendant would be entitled to rely on the defence of consent, providing such consent was informed, which would require disclosure of the defendant's HIV positive status before the sexual interaction.

Under such a construction, the use of the word "duty" by the Court of Appeal ${ }^{121}$ may be explained as a confusing attempt by the Court to illustrate the requirement that where a PHA plans to rely on the defence of consent - presumably because he or she intends to partake in unprotected sexual activity - the PHA is required, and therefore is essentially under a duty, to disclose his or her serostatus. Failure to do so would result in any consent being uninformed and therefore ineffective as a defence, as it fails to meet the requirement of being "full, free and informed". ${ }^{122}$ Adams on Criminal Law, albeit without explanation, assumes that this is the authority that Mwai stands for: that, for the defence of consent to be successful in cases of unprotected sexual intercourse, a

117 See Part IV B 2.

$118 R v$ Mwai, above n 8, 156 Hardie Boys J for the Court.

119 Police v Dalley, above n 1.

120 Wright, above n 9, 670: "Criminal nuisance in these cases in founded on a breach of duty. The duty of a person who is HIV-positive is either to disclose this and obtain the informed consent of a sexual partner, or to use a condom".

$121 R v$ Mwai, above n 8, 156 Hardie Boys $\mathrm{J}$ for the Court.

$122 R v$ Cox (7 November 1996) CA 213/96; $R$ v Herbert (12 August 1998) CA 81/98. 
defendant must disclose his or her HIV positive status, or else the consent will be uninformed and therefore fail. ${ }^{123}$

Support for the contention that disclosure is a prerequisite for the defence of consent, rather than a duty, is also found in the repeated statements of the Court that the duty to use a condom would only arise if there had first been a failure to disclose. ${ }^{124}$ Clearly, such language is inconsistent with the proposition that disclosure is a positive duty as failure to disclose would itself lead to criminal liability, regardless of whether a condom was used. On the other hand, if the Court had intended disclosure to be an alternative duty under section 156 to that of using a condom, the Court would not have used language suggesting a rank or prioritisation of disclosure ahead of using a condom. Instead, it is suggested, language such as "having failed to neither use a condom nor disclose" would have been employed. That a duty to use a condom only arises after a failure to disclose instead suggests that disclosure, through consent, would provide a full a defence to the crime, such that whether a condom was used or not is immaterial.

Additionally, as stated previously, ${ }^{125}$ it is difficult to construe disclosure as plausibly discharging the legal duty, whether statutory or common law derived, implicit in criminal nuisance, as disclosure does not in fact prevent harm: yet avoiding harm ${ }^{126}$ or the exposure to harm, ${ }^{127}$ is the sole requirement of the respective duties. It is unlikely the Court of Appeal would have overlooked such a fundamental point, and by inference could not have intended disclosure to operate as an alternative duty, but as a defence.

Finally, if it is accepted that Mwai is to be considered an authority for imposing an alternative legal duty, rather than a broader general defence, this will cause a disparity in liability depending on whether HIV is actually transmitted. To illustrate this, if disclosure is deemed an alternative legal duty, then disclosing one's HIV positive status obviously discharges that duty and the actus reus of omitting to discharge a legal duty under criminal nuisance would not be fulfilled, ${ }^{128}$ leading to acquittal. However, the same result is not obtained where a defendant actually transmits HIV and is therefore charged with wounding with intent.

123 Hon Bruce Robertson (ed) Adams on Criminal Law (online, Brookers, Wellington, Crimes Act, 1992) paras CA63.10(1), CA63.14 (accessed 31 July 2006)

$124 R v$ Mwai, above n 8, 156 Hardie Boys J for the Court: "...the duty to use a condom would arise only if there were a failure to disclose..." and at 152 "Mwai having failed to warn his sexual partners of his condition, was criminally responsible for not taking the precaution of using a condom" (emphasis added).

125 See Part IV A.

126 Crimes Act 1961, s 156.

$127 R v$ Mwai, above n 8, 156 Hardie Boys $\mathrm{J}$ for the Court.

128 Crimes Act 1961, s 145. 
The result is different under a charge of wounding with intent because, even if disclosure is to be considered an alternative legal duty applicable to all PHAs, disclosure does not defeat any of the legal requirements of intent to wound: the actus reus of grievous bodily harm remains, as HIV has still been transmitted; and the mens rea of recklessness is also unaffected. The mens reas of recklessness is the conscious taking of an unjustifiable risk, ${ }^{129}$ where justifiability is assessed by balancing the likelihood of harm against the value of the conduct. ${ }^{130}$ Accordingly, it is difficult to see how merely disclosing the risk in any way diminishes from the fact it is still "taken" or alters the likelihood of harm. This analysis corresponds to the reasoning at Part IV A which explains why it is impossible to construe disclosure as being either a statutory or common law duty. The only possible argument would be that disclosure increases the value of the conduct, as the conduct is no longer merely sexual activity, but fully informed intercourse with shared and consensual risk-taking. However, such a construction is contrived and, even if accepted, would still have to outweigh the likelihood of harm. ${ }^{131}$ Thus it seems that disclosure, as an alternative duty, may have only negligible impact on recklessness. The overall result being that disclosure would excuse a defendant when HIV was not transmitted, under criminal nuisance yet not when HIV was actually transmitted due to the legal requirements of recklessness. This anomalous result would leave the criminal law in an inconsistent and undesirable position.

\section{$2 \quad R v$ Yong Bum Lee}

The position that Mwai adopted concerning disclosure also came under review in $R v$ Yong Bum Lee (Lee), ${ }^{132}$ where the Court of Appeal faced the issue of whether the defence of consent was available to charges involving the intentional infliction of harm. In reaching a decision, the Court undertook a full analysis of the relevant New Zealand case law concerning consent. The mere inclusion of Mwai in this analysis ${ }^{133}$ suggests it is to be considered, albeit tacitly, as a case concerning disclosure as relevant to the defence of consent. This inference is affirmed by the later observation that "[t]his Court in Mwai took a similar approach to the question of consent as taken [by the English Court of Appeal] in Konzani whereby consent is only relevant if the person is fully informed of all the risks of the activity". ${ }^{134}$ To fully appreciate the significance of this comparison, it is first necessary to explain the approach adopted in Konzani. ${ }^{135}$

$129 R v$ Harney, above $\mathrm{n} 36$.

130 Hilder v Police, above n 81, 236-7 Wylie J.

131 See Part III A.

132 R v Yong Bum Lee, above n 37.

133 Ibid, paras 282-284 Glazebrook J for the Court.

134 Ibid, para 284, Glazebrook J for the Court.

$135 R \vee$ Konzani, above $\mathrm{n}$ 101. Please note however, that a full comparison of the English and New Zealand cases is outside the scope of this paper. 
Preceding the decision in Konzani, the English Court of Appeal held that a defendant charged with inflicting grievous bodily harm ${ }^{136}$ after sexually transmitting HIV had the defence of consent open to him, ${ }^{137}$ provided the complainant was aware of the risk of HIV transmission associated with the sexual conduct. ${ }^{138}$ The issue then before the Court in Konzani concerned the extent of the knowledge required by the complainant about the risk before there was sufficient "awareness" for consent. This arose after counsel for the defendant argued that consenting to any unprotected intercourse was tantamount to consenting to the risk of transmitting HIV, regardless of whether disclosure occurred, given the inherently risky nature of unprotected intercourse. ${ }^{139}$ The Court rejected this submission, ruling that informed consent implicitly requires the defendant must have an honest belief that the complainant was aware of his HIV positive status. ${ }^{140}$ In practice, aside from in exceptional circumstances, ${ }^{141}$ it seems that for a PHA to hold an honest belief that his or her sexual partner is aware of his or her HIV positive status, and therefore safely rely on the defence of consent, there will be an obligation to disclose this status. ${ }^{142}$

The comparison between Konzani and Mwai by the Court of Appeal is therefore notable. It implies not just that Mwai, like Konzani, is an authority for the defence of consent but goes further, asserting that, as argued above, Mwai requires consent to be informed. In order for consent to be informed, a sexual partner must be aware of the risks involved, or else the defence is not available; this effectively imposes an obligation to disclose one's HIV positive status. This view is confirmed where, while elucidating the limits to the defence of consent, the Court stated in obiter dicta: ${ }^{143}$

Cases such as Konzani and Mwai suggest that any consent must also be informed... [Imposing a] requirement [on the person seeking consent, to correct an information imbalance about the risks involved in an activity] may, however, be limited to cases where the risk is major because of the very serious consequences if it does eventuate (such as with unprotected sex and HIV).

136 Offences Against the Person Act 1861 (UK), s 20.

137 This did not expressly overturn the established position of $R v$ Brown, above $\mathrm{n}$ 37, that a person cannot consent to the infliction of harm. This is because consenting to intercourse with a PHA was not consenting to the actual infliction of harm, but merely consenting to running the risk of harm: $R v$ Dica, above $\mathrm{n} 98$, para 47, Judge LJ for the Court.

$138 R$ v Dica, above n 101.

$139 R$ v Konzani, above n 101, para 5, Judge LJ for the Court.

140 Ibid, paras 42-44, Judge LJ for the Court.

141 The case lists some - arguably uncommon - examples of when disclosure may not be required to hold an honest belief. For example a PHA who develops a sexual relationship with someone who knew him while he was in hospital receiving treatment for the virus, or where a mutual friend has told his sexual partner of defendant's status: ibid, para 44, Judge LJ for the Court.

142 Weait, above n 112, 766.

$143 R v$ Yong Bum Lee, above n 37, para 309, Glazebrook J for the Court. 
Such a statement, while clearly not definitive, is strongly suggestive that a defence of informed consent implies an obligation to disclose.

3 Conclusions from the case law

Drawing together the implications from all of the case law, two major conclusions about the courts' view on disclosure can be deduced. First, where the risk of transmitting HIV is below a material level, either because the risk of the sexual conduct is inherently below this level or because precaution was taken to lower the risk beneath this level, a defendant will not be considered criminally liable; ${ }^{144}$ consequently, whether disclosure occurred is immaterial. ${ }^{145}$ Clearly, the courts are not imposing a positive duty to disclose whenever engaging in any sexual activity, despite this being the conclusion some subsequent cases have drawn about Lee. ${ }^{146}$ Instead, disclosure is relevant only to sexual conduct where the risk of harm is above a material level.

Secondly, the effect of Lee in deeming disclosure to be relevant to the defence of consent implies it is not considered an alternative duty, but a component of informed consent. For consent to be informed, the person giving consent must be fully aware of the risk of the activity and, as sexual activity with a PHA obviously entails a greater risk of the harm of HIV, this means he or she needs to be aware whether his or her sexual partner is HIV positive. Therefore, where a complainant is not already aware that his or her sexual partner is HIV positive, the sexual partner will be required to disclose this in order to rely on the defence of consent. ${ }^{147}$ Nonetheless, an issue that remains unresolved concerning disclosure and informed consent is the level of knowledge that the courts will require a prospective sexual partner to have before consent will be deemed informed. It is possible that the courts will follow the position adopted in Konzani that knowledge is subjective; hence if a defendant honestly believed that his or her sexual partner was aware he or she was HIV positive, this would meet the standard of informed consent. ${ }^{148}$ Although relatively quiet on the point in Lee - now the pre-eminent decision regarding consent in New Zealand - the language of the Court does appear to assume that an honest belief in consent will be sufficient. ${ }^{149}$

144 Police v Dalley, above n 1 . See Part III C for a justification of why Dalley should be interpreted to require a material level of risk of harm.

145 Police v Dalley, above n 1, para 43 Judge Thomas.

146 CLM v Accident Compensation Corporation (12 May 2006) HC WN CIV 2005-485-000893, para 73 Randerson J.

147 R v Yong Bum Lee, above n 37, para 309 Glazebrook J for the Court.

$148 R$ v Konzani, above n 101, paras 42-44 Judge LJ for the Court.

$149 R v$ Yong Bum Lee, above $\mathrm{n}$ 37, para 308 Glazebrook $\mathrm{J}$ for the Court: "Consent is only a defence if what was done does not exceed what was consented to or what a perpetrator honestly believed was consented to". 
While a full discussion of knowledge and consent is outside the ambit of this paper, the author believes that the focus in Konzani on whether a complainant simply knows of the defendant's HIV positive status ${ }^{150}$ is too myopic. The issue extends to whether that complainant also understand the risks and consequences associated to sexual activity with a PHA; for consent is no more informed where a person knows they are partaking in sexual conduct with a person who is HIV positive, yet is not aware that HIV is a life-threatening virus, or is seriously misguided as to its perceived antidotes or effects.

It is argued that, irrespective of whether a standard of actual knowledge or mere honest belief about the risk of the activity is imposed, the courts should construe knowledge so as to require that the complainant actually knows the defendant is HIV positive. Such a requirement is justified on the basis that any additional onus on PHAs to ensure their partners are aware of their HIV positive status through disclosure is heavily outweighed by the harm suffered by a person who has unprotected intercourse without knowing their partner is HIV positive.

If the base requirement that a complainant must be aware of the defendant's HIV positive status for the defence of consent to operate is accepted, the court must then determine the level of understanding that this knowledge must entail. On the one hand if the courts decide to adopt a standard of actual knowledge, this would translate to ensuring a complainant appreciated the true risks and consequences of HIV transmission associated with sexual activity. Conversely, if the courts only require an honest belief of informed consent, a defendant must still be satisfied that a complainant knows of his or her HIV positive status; however the defendant only needs to honestly believe, rather than ensure, that the complainant is actually aware of the consequences and risks that sexual activity will involve. This paper serves only to highlight the potential divergence open to the law; evaluating which path is more desirable would require extensive assessment.

\section{CONCLUSION}

The criminal law encompasses the sexual transmission of HIV through the general sections of the Crimes Act. Both intentional and reckless transmission of HIV are covered through the charges of "infecting with disease"151 and "intent to wound" respectively. ${ }^{152}$ Further, as PHAs have a potentially fatal virus under their control, they are considered to be under a legal duty to avoid harm. ${ }^{153}$ Failing to discharge this duty means that even where no transmission of HIV occurs, a PHA may nonetheless be liable under a charge of criminal nuisance. However, while the courts have readily accepted that the sexual conduct of PHAs is subject to the criminal law, they have not clearly outlined the legal boundaries of such criminalisation. This paper has endeavoured to clarify

$150 R v$ Konzani, above n 101, paras 42-44 Judge LJ for the Court.

151 Crimes Act 1961, s 201.

152 Crimes Act 1961, s 188(2).

153 This duty may be statutory or common law derived: see Part II C. 
the most desirable path the law could follow regarding two major ambiguities, the relevancy of risk and disclosure, on the two offences of recklessness.

This paper argues that a material level of risk of harm needs to be established by policy-makers. Where a PHA exposes another individual to a risk of harm above this material threshold, the legal duty he or she is under would require precautions to be taken to reduce this level of harm to below the material threshold. Failure to do so would result in a charge of intent to wound if HIV was contracted, or criminal nuisance where there was no transmission. No criminal liability would ensue if a PHA exposed another individual to a risk of harm below this threshold.

This can be achieved simply by interpreting "endanger" in criminal nuisance as implying a material risk of harm, rather than merely any risk of harm. The harm-based nature of the criminal law suggests offences should have such a rational connection between risk and culpability. Consequently, this will ensure that risk of harm continues to be regarded as the essential element in offences of recklessness, and that consistent outcomes between the two offences are obtained. Finally, if a PHA exposes a sexual partner to a risk of harm in excess of the designated level of risk, recent case law seems to suggest that disclosing one's HIV positive status to a sexual partner will allow a PHA to rely on the defence of informed consent.

This proposed framework remedies two ambiguities of the criminalisation of sexual HIV transmission and promotes consistent and rational application of the law. The legal framework, although not ideal, nonetheless creates definite parameters within which PHAs can lawfully conduct their sexual activity. PHAs, who already face societal stigmatisation ${ }^{154}$ and the effects of a lifethreatening disease, should at the very least be able to rely on being subject to a criminal law that is both certain and rational.

154 New Zealand AIDS Foundation www.nzaf.org.nz (accessed 12 July 2006). 